\title{
高速衝突を受けたコンクリート板の火災加熱に対する温度性状 TEMPERATURES IN CONCRETE PLATE EXPOSED TO FIRE AFTER HIGH VELOCITY IMPACT
}

\author{
森田 武*, 別府万寿博**, 鈴木 誠*** \\ Takeshi MORITA, Masuhiro BEPPU and Makoto SUZUKI
}

\begin{abstract}
Projectiles would be released by an accident such as explosions, and impinge on structures. Airplanes, cars and so on can also be impact objects. The explosion and clash occasionally cause fire if there are fire load like oil, fuel and any other combustible materials. Local damage of concrete structures, i.e. spalling, scabbing, perforation, would occur if the concrete structures are impacted by high velocity projectiles. Scabbing and perforation must be prevented in order to protect people and any other properties inside of the structure. Moreover if fire is assumed to occur after the impact, fire must not spread to other compartments or spaces. Therefore, fire tests on concrete plates impacted by high velocity projectiles were carried out in order to know fire behavior of the concrete plates. In addition, temperatures in concrete plates were numerically calculated in order to know the inside temperatures. As the results of study, cracks produced in concrete plates spalled by impact lead to less effect on thermal insulation performance of the plates.
\end{abstract}

Keywords : High velocity impact, Local damage, Concrete plate, Fire exposure, Thermal insulation 高速衝突，局部破壊，コンクリート板，火災加熱，遮熱性

\section{1. はじめに}

近年，爆発事故や自然災害によって衝撃的な荷重がコンクリート 構造物に作用し，損傷や破壊が生じるケースが増加している。

衝撃荷重を受けるコンクリート構造物の破壊は，全体破壊と局部 破壞に大きく分類できる 1)。飛翔体がコンクリート構造物に高速度 で衝突すると, 衝突条件によっては表面破壊（衝突面の破壊），裏面 剥離（衝突面と反対面のコンクリートの剥離），貫通（表面破壊と裏 面剥離が連結して飛翔体が裏面側へ貫通する破壊）等の局部破壊を 生じる 2)。このような局部破壊が生じると, 構造部材の剛性や強度 を低下させるだけでなく, 裏面剥離や貫通に至る場合には裏面に飛 散物を生じる。このような飛散物による危険から構造物内の人命や 財産を守るためには, 貫通や裏面剥離を防止寸る必要がある。そこ で著者らは，衝突荷重を受けるコンクリート板の裏面剥離を防止す るための対策技術としてコンクリートの短繊維補強に着目し, 高速 衝突実験等による検討によって，その有効性を確認した 3 。

一方，危険物取扱い施設等での爆発にともなう飛散物の衝突，発 電施設等でのタービンブレードの破損飛散による衝突，あるいは一 般の構造物一の航空機や車両の衝突などが発生した場合, 衝突作用 後の構造物の内部あるいは外部において, 燃料・化学品・油などと いった種々の可燃物の燃焼による火災が発生する可能性がある。衝
撃作用後に火災が発生する場合を想定すると, 構造物内の人命や財 産を守るためには，衝突だけでなく，衝突後の火災に対しても構造 物の安全性が担保される必要がある。そのためには, 衝突作用とそ の後の火災に対して部材・構造体の構造安定性を確保するとともに, 火災が屋内で発生した場合には隣接する室等への延焼を，屋外で発 生した場合には屋内への延焼を防止する必要がある。

しかしながら，火災時における構造体の温度性状や構造挙動に関 して，局部破壊がどのような影響を及ぼすかについては，これまで に検討された例は見当たらない。衝突作用を受けたコンクリート構 造体においては，貫通・裏面剥離が防止されたとしても，表面破壊 や内部ひび割れなどの損傷が生じている可能性がある。そのため, 衝撃作用後の火災に対するコンクリート構造体の安全性を評価する ためには，衝突作用による表面や内部の損傷が，火災時にどのよう な影響を及ぼすかについて把握する必要がある。

本研究では, 衝突作用後に火災を受けるコンクリート構造物の安 全性評価手法の構築に資するべく, 剛飛翔体の衝突によって損傷し たコンクリート板が衝突面側から火災加熱を受けた場合の温度性状 を把握することを目的とした。本研究はコンクリート板に対する高 速衝突実験と加熱実験、および加熱を受けるコンクリート板の温度 性状に関寸る解析的検討で構成される。高速衝突実験ではコンクリ
* 清水建設(侏)技術研究所 主任研究員 ·博士 (工学)

** 防衛大学校システム工学群建設環境工学科 准教授・博士 (工学)

*** 清水建設(株)技術研究所 副所長 · 工博
Senior Research Engineer, Institute of Technology, Shimizu Corporation, Dr. Eng. Assoc. Prof., Department of Civil and Environmental Engineering, National Defense Academy, Dr. Eng.

Deputy Director, Institute of Technology, Shimizu Corporation, Dr. Eng. 
一トに対する短繊維補強の有無, 鉄筋補強の有無, 飛翔体の衝突速 度などを実験パラメータとした。そして, 高速衝突実験に供した試 験体を耐火試験炉で片側から加熱し，コンクリート板裏面における 温度性状等を調べた。さらに, 衝突実験と加熱実験の結果を踏まえ て，表面破壊や内部ひび割れの影響を伝熱解析によって検討した。 なお，高速衝突実験は既報 3)で報告した実験と同時に行った。

\section{2. 実験方法}

(1) コンクリート板試験体

(1) コンクリート

表 1 にコンクリートの使用材料を, 表 2 に調合と圧縮強度を示す。 ベースコンクリートは水セメント比 $55 \%$ の普通コンクリートとし た。短繊維補強には長さ $20 \mathrm{~mm}$ のポリプロピレン短繊維（以下, PP と称す。）を用いた。表 2 の調合名は, PLAIN がプレーンコン クリートを意味し, それ以外の短繊維補強コンクリートは, 纎維種 類・長さ・混入率を示寸表記とした。短繊維の混入率はコンクリー 卜体積に対して外割りで $0.5,1.0 \mathrm{vol} \%$ とた。コンクリートの空気 量は空気量調整剤を適宜添加して，約 $5 \%$ になるように調整した。

(2) 試験体の形状・寸法

試験体の形状・寸法を図 1 に示す。試験体は，無筋および鉄筋を 格子状に配した $500 \mathrm{~mm} \times 500 \mathrm{~mm} \times 80 \mathrm{~mm}$ の 2 種類のコンクリート 板とした。鉄筋にはD6（SD295A）を使用し，縦筋と横筋を $100 \mathrm{~mm}$ 間隔で配してダブル配筋とした。

(3) 試験体の種類

表 2 に示す調合ごとに無筋コンクリート板を 2 体製作し, PLAIN については，鉄筋コンクリート板（以下， RC と称す。）も2 体製作 した。各仕様 2 体のうち 1 体は耐火実験用, もう 1 体は衝突実験後 の断面観察用とした。試験体は，コンクリート打設後 28 日間 $20^{\circ} \mathrm{C}$ の水中で養生し, その後は衝突実験に供するまで気中養生とした。 また, 衝突実験後の加熱実験までの期間も再度気中養生とした。

\section{(2) 高速衝突実験}

高速衝突実験には, 高圧空気式飛翔体発射装置を使用した。試験 装置の模式図を図 2 に, 飛翔体を写真 1 に示寸。装置は, 圧縮器・ 増圧器・エアチャンバー・発射管（長さ $12 \mathrm{~m}$, 内径 $35 \mathrm{~mm}$ ）で構成 されており，圧縮空気で飛翔体を発射・加速する。衝突速度は図 2 の発射口に設置したレーザー式速度検出センサーで測定される。

本実験では, 直径 $25 \mathrm{~mm}$, 質量 $46 \mathrm{~g}$ で, 先端形状が半球型の鋼製 （SS400）の剛飛翔体を使用した。剛飛翔体の衝突速度は, 既往の 実験結果 4 )を参考にして, PLAIN の無筋コンクリート板において裏 面剥離を生じずに表面破壊で止まる速度 $215 \mathrm{~m} / \mathrm{s}$ と裏面剥離を生じ る速度 $315 \mathrm{~m} / \mathrm{s}$ の 2 水準とした。

\section{（3）加熱実験}

加熱実験には，都市ガスを燃料とする小型壁炉を使用した。加熱 試験装置と試験装置に組み込んだ試験体の加熱面の状況を写真 2 に
示す。小型壁炉にはガスバーナーが 4 基，炉内温度測定用の熱電対 が 5 本設置されている。师内温度はプログラム設定器によって所定 の温度に自動で制御される。試験体の加熱面の周囲 $25 \mathrm{~mm}$ は試験体 設置枠に押し当てるため, 有効加熱面積は $450 \mathrm{~mm} \times 450 \mathrm{~mm}$ である。 本実験では試験体の衝突面を加熱面とし，裏面（衝突面と反対側 の面）は炉外の常温空気に暴露される条件で行った。加熱温度条件 は，燃料火災を想定して，炭化水素火災を模した標準加熱温度時間 曲線 5)に準じた加熱を 2 時間行うこととした。測定項目は加熱温度 と試験体の裏面温度とし, 裏面温度の測定には赤外線サーモグラフ イを使用した。

表 1 コンクリートの使用材料

\begin{tabular}{|c|c|}
\hline 材料 & 種類・物性など \\
\hline セメント & 普通ポルトランドセメント \\
\hline 粗骨材 & 硬質砂岩（砕石2005, 青梅産) \\
\hline 細骨材 & 山砂（君津法木产山砂） \\
\hline 混和剤 & AE減水剤（標準形（I種）），AE凰（I 種）、空気量調整剤 \\
\hline 短繊維 & $\begin{array}{l}\text { 長さ : } 20 \mathrm{~mm}, \text { 直径 : } 0.05 \mathrm{~mm} \\
\text { 密度 : } 0.91 \mathrm{~g} / \mathrm{cm}^{3} \text {, 引張強度 : } 299 \mathrm{~N} / \mathrm{mm}^{2}\end{array}$ \\
\hline
\end{tabular}

表 2 調合・圧縮強度・含水率

\begin{tabular}{|c|c|c|c|c|c|c|c|c|c|c|}
\hline \multirow{3}{*}{ 調合名 } & \multicolumn{6}{|c|}{ ベースコンクリート } & \multirow{3}{*}{$\begin{array}{c}\text { 綫維 } \\
\text { 混入率 } \\
(\text { vol\%) }\end{array}$} & \multirow{2}{*}{\multicolumn{2}{|c|}{$\begin{array}{c}\text { 圧縮強度 } \\
\left(\mathrm{N} / \mathrm{mm}^{2}\right)\end{array}$}} & \multirow{3}{*}{$\begin{array}{c}\begin{array}{c}\text { 含水率 } \\
(\mathrm{wt} \%)\end{array} \\
\text { 加熱時 }\end{array}$} \\
\hline & \multirow{2}{*}{\begin{tabular}{|l|}
$W / C$ \\
$(\%)$
\end{tabular}} & \multirow{2}{*}{$\begin{array}{l}\text { s/a } \\
(\%)\end{array}$} & \multicolumn{4}{|c|}{ 単位量※1 $\left(\mathrm{kg} / \mathrm{m}^{3}\right)$} & & & & \\
\hline & & & W & $\mathrm{C}$ & $S$ & $\bar{G}$ & & 28 日 2 & 実験 $* 3$ & \\
\hline PLAIN & \multirow{3}{*}{55} & \multirow{3}{*}{46} & \multirow{3}{*}{175} & \multirow{3}{*}{318} & \multirow{3}{*}{817} & \multirow{3}{*}{973} & $=$ & 33.1 & 41.0 & 未測定 \\
\hline PP20-05 & & & & & & & 0.5 & 31.2 & 40.0 & 3.3 \\
\hline PP20-10 & & & & & & & 1.0 & 28.3 & 34.3 & 3.1 \\
\hline
\end{tabular}

$※ 2$ 材齢 : 28 日、標淮盖生

$※ 3$ 実験期間平均（材齢：2 5 月 7 ケ月）、試験体同一養生（気中養生）
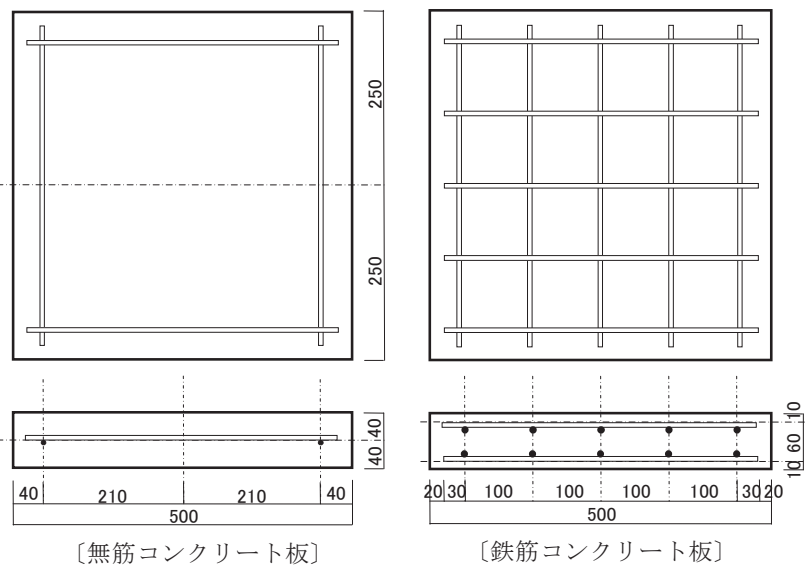

図 1 コンクリート板試験体の形状・寸法

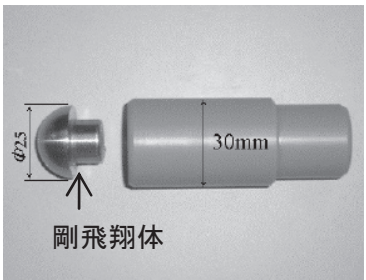

写真1 剛飛翔体および固定具

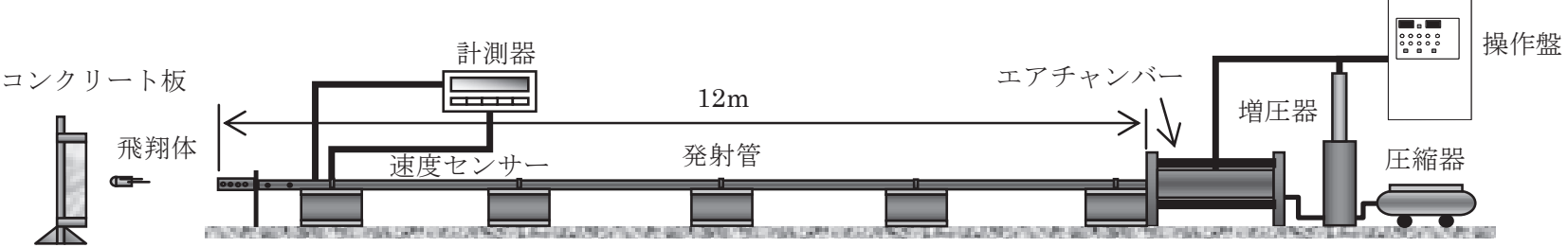

図 2 高圧空気式飛翔体発射装置の概要 


\section{3. 高速衝突実験結果}

実験時に測定された剛飛翔体の衝突速度は, 設定速度 $215 \mathrm{~m} / \mathrm{s}$ に 対して $210.6 \sim 216.0 \mathrm{~m} / \mathrm{s}$, 設定速度 $315 \mathrm{~m} / \mathrm{s}$ に対して $312.5 \sim$ $315.5 \mathrm{~m} / \mathrm{s}$ であった。以下では, 設定衝突速度を単に衝突速度と言う。 衝突実験で局部破壊した試験体の貫入深さと表面破壊の平均直径, 裏面剥離深さと平均直径を表 3 に示す。試験体名は, コンクリート の調合と衝突速度 $(2: 215 \mathrm{~m} / \mathrm{s}, 3: 315 \mathrm{~m} / \mathrm{s})$ を示す表記とした。 衝突実験後の試験体の局部破壊の状況は後掲の写真 3,4 に示す。

各試験体の局部破壊モード(表面破壊・裏面剥離・貫通) は, PLAIN においては, 衝突速度 $215 \mathrm{~m} / \mathrm{s}$ に対して表面破壊, $315 \mathrm{~m} / \mathrm{s}$ に対して 裏面剥離であった。 RC においても PLAIN と同様に, 衝突速度 $215 \mathrm{~m} / \mathrm{s}$ に対して表面破壊， $315 \mathrm{~m} / \mathrm{s}$ に対して裏面剥離であった。短 繊維補強した試験体では, 衝突速度 $215 \mathrm{~m} / \mathrm{s}$ と $315 \mathrm{~m} / \mathrm{s}$ の双方で表 面破壊を生じたが, 裏面剥離は生じなかった。損傷状況を測定した 結果, 表面破壊の最大貫入深さは, 衝突速度 $215 \mathrm{~m} / \mathrm{s}$ で $14 \sim 18 \mathrm{~mm}$, $315 \mathrm{~m} / \mathrm{s}$ で 21〜 29mm であった。裏面剥離の最大深さは $28 \sim 33 \mathrm{~mm}$, 平均直径は 215 230mm であった。また, 今回と同条件で高速衝 突実験を実施した試験体の切断面に関して, 衝突速度 $215 \mathrm{~m} / \mathrm{s}$ では 視認できるひび割れはなかったが， $315 \mathrm{~m} / \mathrm{s}$ では板内部から裏面近 くまで斜め方向に生じたひび割れ（以下，斜めひび割れという。後 掲の図 6 と写真 5 参照。）が認められた ${ }^{3)}$ 。本報の試験体と同条件の 試験体 3)のひび割れ幅は PL-3 と RC-3 で 0.80 0.85mm 程度, P05-3 で $0.45 \sim 0.75 \mathrm{~mm}$ 程度， $\mathrm{P} 10-3$ で $0.45 \sim 0.55 \mathrm{~mm}$ 程度であった。

\section{4. 加熱実験結果および考察}

加熱実験時の炉内温度の測定結果の一例を図 3 に示し, 各試験体 の加熱前と加熱後の状況, および加熱中における裏面の状況と赤外 線サーモグラフィの熱画像を写真 3,4 に示寸。また, 各試験体の 熱画像から画像解析ソフトによって読夕取った試験体の中央高さ幅 方向における裏面温度分布を図 $4 ， 5$ に示す。なお，加熱中の裏面 状況と熱画像は, 試験体を固定したアングル（写真 2 参照）部分を 除いた，高さ $40 \mathrm{~cm} \times$ 幅 $50 \mathrm{~cm}$ の範囲を示した。

\section{(1) 目視観察}

\section{(1) 加熱による損傷}

写真 $3 ， 4$ に示すように，加熱・冷却期間を通じて，裏面におい てコンクリート片が剥落するなどの外見上の損傷の拡大は認められ なかった。加熱面については，加熱後に状況を観察したところ， $1100^{\circ} \mathrm{C}$ で約 2 時間加熱されたためにコンクリートの色が淡黄色に変 色していたが，コンクリートの爆裂や剥落は認められなかった。

(2) 裏面の変化

いずれの試験体においても, 加熱開始後約 8 分経過した頃から, コンクリートの含有水が裏面に湧出し始めた。含有水の湧出は, 衝 突速度 $215 \mathrm{~m} / \mathrm{s}$ の試験体では放射状に, 衝突速度 $315 \mathrm{~m} / \mathrm{s}$ の試験体 では放射状および円状に生じた。そして約 60 分経過した時点では, 含有水の湧出はなく, 裏面が乾燥した状態になった。衝突速度 $215 \mathrm{~m} / \mathrm{s}$ の試験体では衝突位置を中心にして放射状に広がったひび 割れ（以下，放射状ひび割れという。）, 衝突速度 $315 \mathrm{~m} / \mathrm{s}$ では放射 状ひび割れと円状のひび割れ（斜めひび割れは立体的には円錐状に 形成されており，これを衝突面に正対して見ると円状のひび割れに 見える。以下，円状ひび割れという。）が，裏面あるいは裏面近傍ま

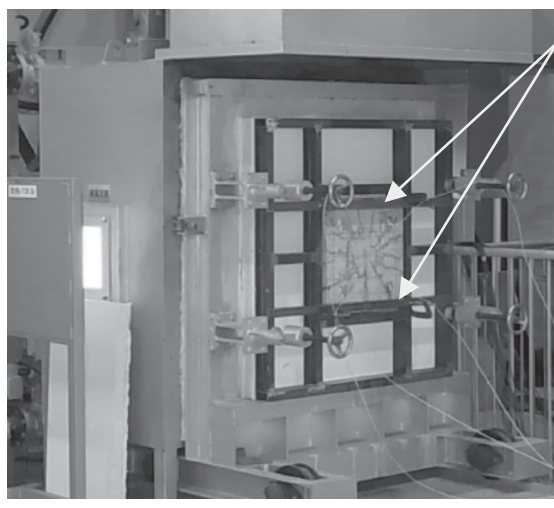

試験体の上下を鋼材 (L-40×40×5 mm) で固定 (アングル間内法寸法 : $40 \mathrm{~cm})$ 。 試験体の四周にはセラミ ックファイバーを充填。

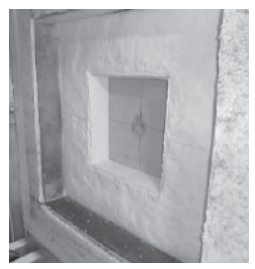

写真2 加熱試験装置（左）と試験体の加熱面（右）

表3高速衝突実験による局部破壊の状況

\begin{tabular}{|c|c|c|c|c|c|c|}
\hline \multirow{2}{*}{ 試験体 } & \multirow{2}{*}{ シンクリート } & 衝突速度 & \multicolumn{2}{|c|}{ 表面破壊 $(\mathrm{mm})$} & \multicolumn{2}{|c|}{ 裹面剥離 $(\mathrm{mm})$} \\
\cline { 4 - 7 } & & $\mathrm{m} / \mathrm{s})$ & 最大深さ & 平均直径 & 最大深さ & 平均直径 \\
\hline PL-2 & PLAIN & 215.9 & 16 & 96 & - & - \\
\hline PL-3 & PLAIN & 312.5 & 22 & 109 & 33 & 230 \\
\hline RC-2 & PLAIN & 214.4 & 14 & 71 & - & - \\
\hline RC-3 & PLAIN & 314.8 & 21 & 117 & 28 & 215 \\
\hline P05-2 & PP20-05 & 216.0 & 18 & 81 & - & - \\
\hline P05-3 & PP20-05 & 314.7 & 29 & 117 & - & - \\
\hline P10-2 & PP20-10 & 210.6 & 16 & 86 & - & - \\
\hline P10-3 & PP20-10 & 315.0 & 29 & 95 & - & - \\
\hline
\end{tabular}

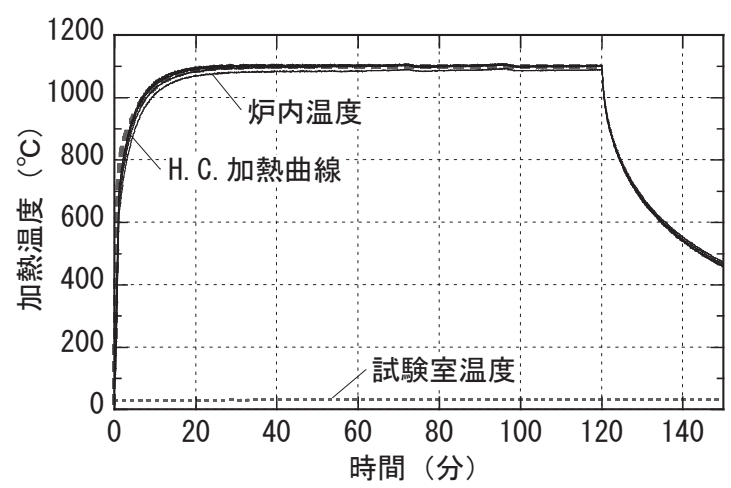

図3 加熱温度の測定結果（P10-2）

で到達していたために，これらのひび割れを通じてコンクリート内 部から含有水が湧出したものと言える。

短繊維補強した試験体では，裏面においてひび割れからの含有水 の湧出がなくなった後, 短繊維の熱分解ガスと思われる臭気があっ た。また, 裏面のひび割れが黒く変色しており, 短繊維の熱分解成 分が付着したものと考えられる。

\section{（2）熱画像による裏面温度}

(1)放射状ひび割れの影響

加熱開始後 20 分の熱画像では，コンクリート表面温度よりも， ひび割れを通じてコンクリート内部から湧出してきた含有水の温度 の方が 20〜 $30^{\circ} \mathrm{C}$ 程度高い傾向を示した。40 分の熱画像では, 逆に, ひび割れのない部分のコンクリート表面温度よりも，ひび割れ部の 温度の方が若干低い傾向を示した。これはひび割れから涌出した水 の蒸発潜熱による影響と考えられる。しかし，含有水の湧出がなく なり, 裏面が乾燥した状態になると, 加熱開始後 60 分の熱画像に 示されるように, ひび割れのない部分とひび割れ部の温度差は見ら れない。したがって，放射状ひび割れは，コンクリート板の遮熱性 能の弱点になることはないと判断される。

(2) 斜めひび割れ（円状ひび割れ）の影響

放射状ひび割れと同様に, 加熱開始後 20 分の熱画像では, ひび 


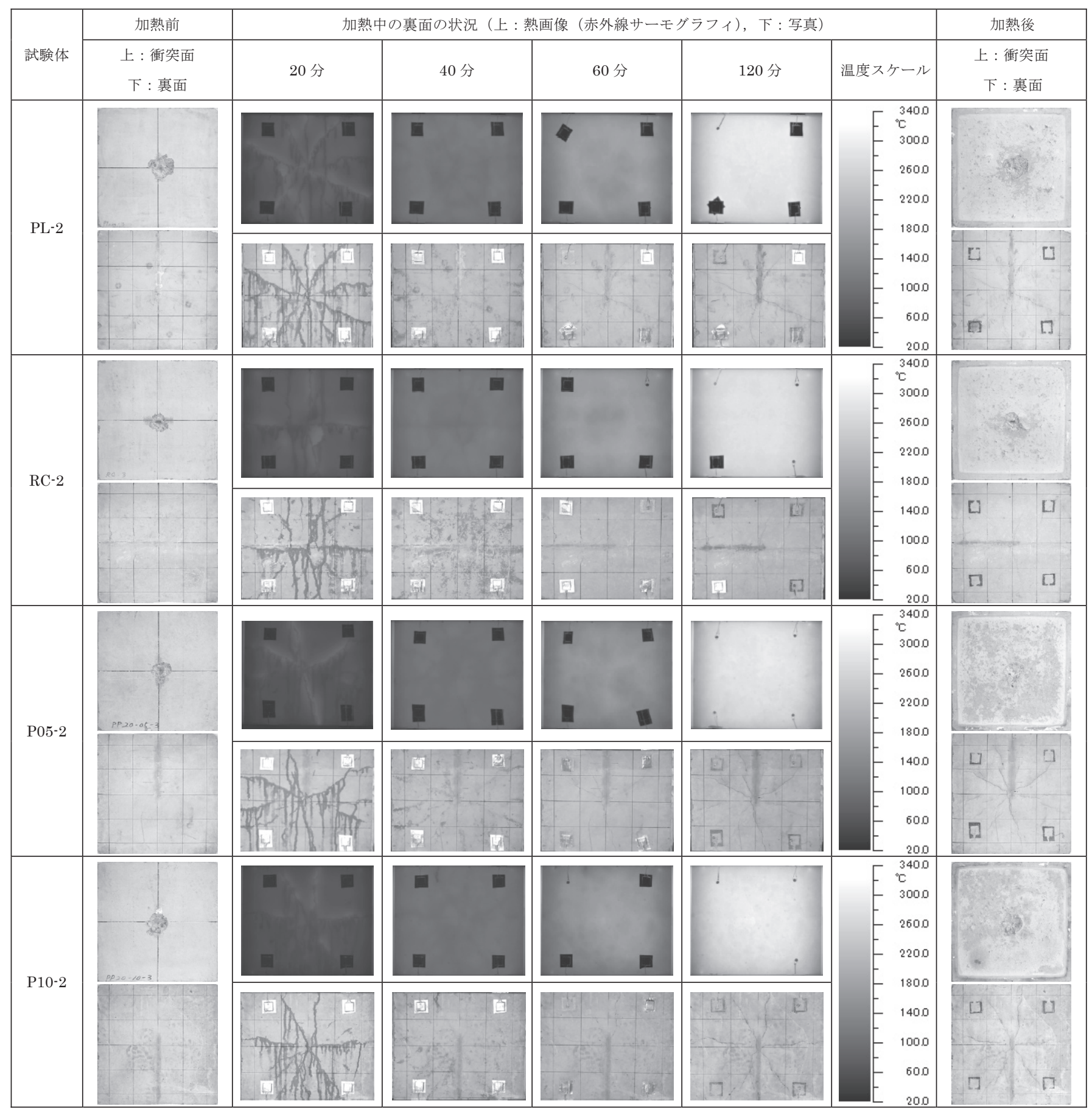

写真 3 衝突速度 $215 \mathrm{~m} /$ の試験体の加熱前・加熱中・加熱後の状況

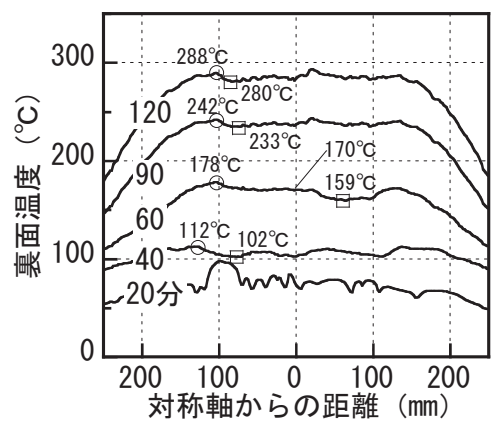

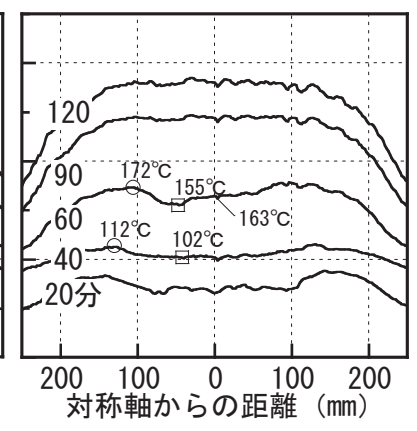

【RC-2】

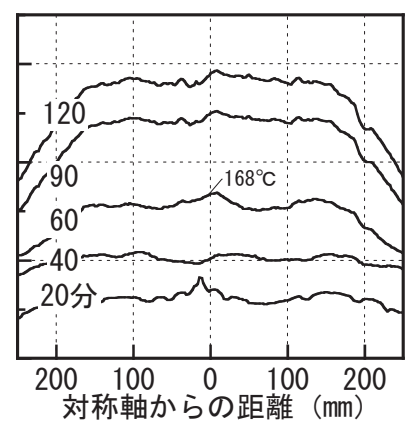

【P05-2】

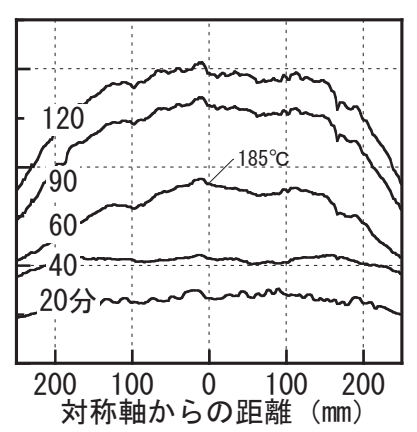

【P10-2】

図 4 衝突速度 $215 \mathrm{~m} / \mathrm{s}$ の試験体の中央高さ幅方向における裏面温度分布

$(\bigcirc, \square は 円$ 状ひび割れの外側の最高温度 $(\bigcirc)$ と内側の最低温度 $(\square))$ 


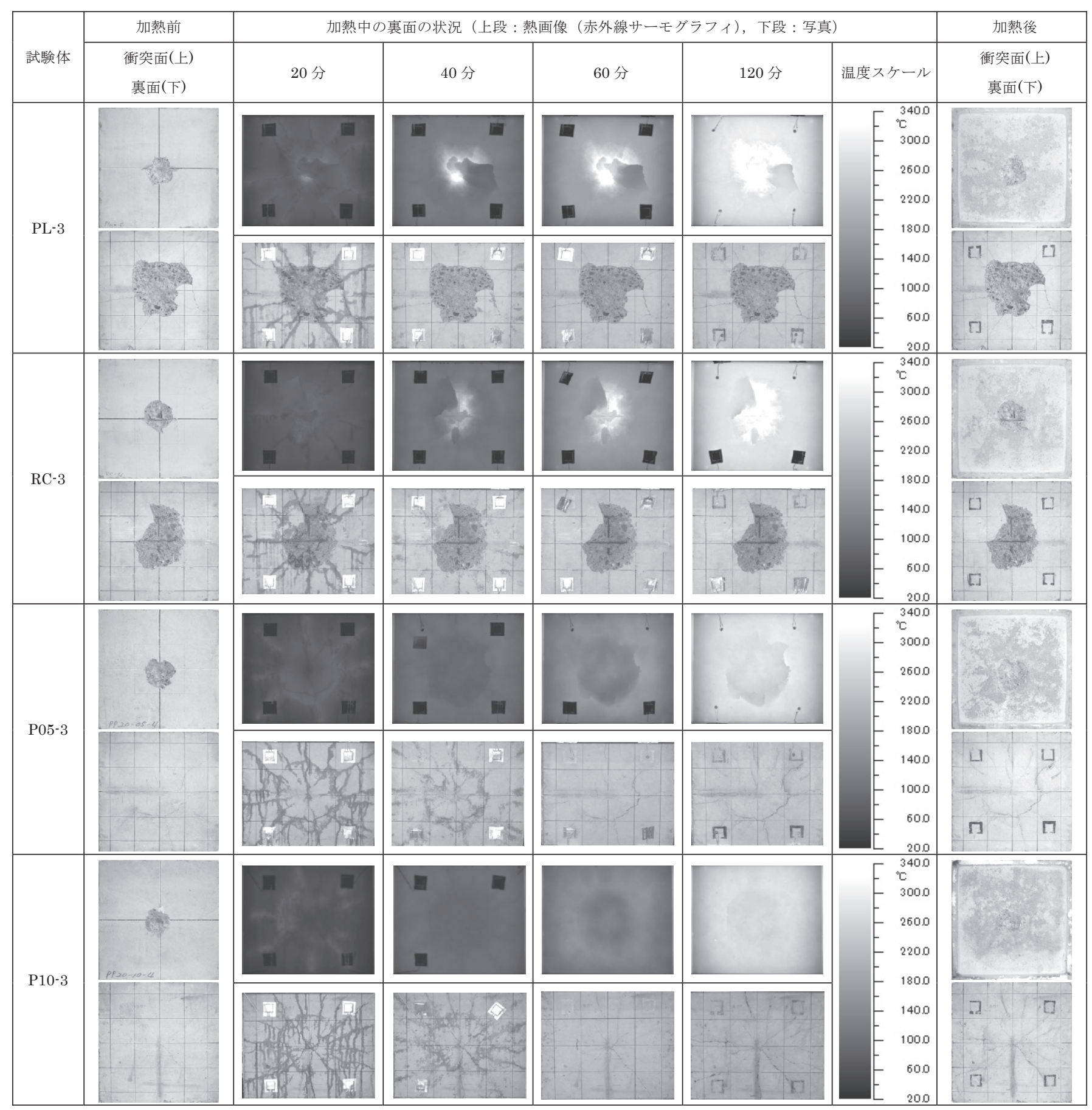

写真 4 衝突速度 $315 \mathrm{~m} / \mathrm{s}$ の試験体の加熱前 - 加熱中 - 加熱後の状況
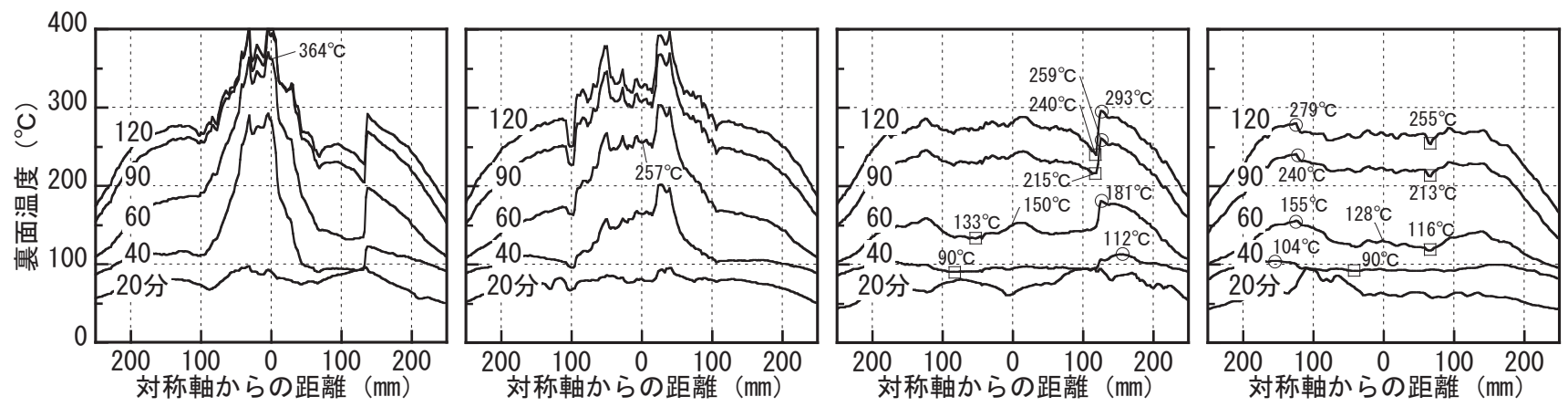

【PL-3】

【RC-3】

【P05-3】

【P10-3】

図 5 衝突速度 $315 \mathrm{~m} / \mathrm{s}$ の試験体の中央高さ幅方向における裏面温度分布

$(\bigcirc, \square$ 状ひび割れの外側の最高温度 $(\bigcirc)$ と内側の最低温度 $(\square))$ 
割れを通じてコンクリート内部から湧出してきた含有水の温度がコ ンクリート表面温度よりも $20 \sim 30^{\circ} \mathrm{C}$ 程度高い傾向を示した。写真 3 , 4 に示した加熱中の熱画像では円状ひび割れの外側よりも内側の方 がコンクリート表面温度は低くなっており, 図 4，5 から, PL-2 で $8 \sim 19^{\circ} \mathrm{C}, \mathrm{RC}-2$ で $10 \sim 17^{\circ} \mathrm{C}(90,120$ 分では明確な差異は見られな い), P05-3 で $22 \sim 53^{\circ} \mathrm{C}, \mathrm{P} 10-3$ で $14 \sim 39^{\circ} \mathrm{C}$ 差が生じている。放 射状ひび割れは加熱面から裏面への熱エネルギーの移動方向に平行 な面に形成されているために熱抵抗とはならない。しかし, 円状ひ び割れは熱エネルギーの移動方向に対して角度を持った面に形成さ れているために熱抵抗となる。そのため, 円状ひび割れの内側の裏 面温度が低くなったと言える。このように, 斜めひび割れの影響で 裏面温度が高くなることはないことから, 斜めひび割れは, 放射状 ひび割れと同様に, 遮熱性能の弱点にならないと判断される。

(3)表面破壊と裏面剥離の影響

写真 3, 4 の加熱 60 分の熱画像および図 4, 5 から, PL-2, P05-3 および P10-3 では，表面破壞で生じた断面欠損により，表面破壊位 置の真裏の裏面温度が若干高くなる傾向が見られる。また, 裏面剥 離していない試験体 PL-2 $・$ RC-2 と裹面剥離した試験体 PL-3・RC-3 の 60 分における板の中心部分の裏面温度は, PL-2 が $170^{\circ} \mathrm{C}, \mathrm{RC}-2$ が $163^{\circ} \mathrm{C}$ であるのに対して, PL-3 が $364^{\circ} \mathrm{C}, \mathrm{RC}-3$ が $257^{\circ} \mathrm{C}$ であり， 顕著な差が見られる。遮熱性能の確保には, 斜めひび割れが裏面に 達しても剥離片が剥落しないようにすることが重要であると言える。

\section{5.コンクリート板の温度性状に関する解析的検討}

高速衝突を受けたコンクリート板が火災加熱を受けた場合の裏面 温度性状は加熱実験によって把握することができたが，コンクリー 卜板内部の温度性状については実験で把握できていない。一方, 構 造物内の人命や財産に局部破壊による危害を及ぼさないことを前提 と寸れば, 裏面剥離や貫通は防止されなければならない。そこで, 裏面剥離が抑制されたコンクリート板を対象に伝熱解析を試み, 表 面破壞や斜めひび割れがコンクリート板の裏面および内部の温度性 状に及ぼす影響を検討することとした。

\section{(1) 解析方法}

解析には差分法 6,7)を適用した非定常熱伝熱解析プログラム8)を用 いた。差分法では, 解析対象断面を微小要素に分割し, 要素内は一 様温度として取り扱う。各要素の温度は, 解析時間を微小時間間隔 $\Delta \mathrm{t}$ に分割し, $\Delta \mathrm{t}$ 内における要素の温度を一定温度とした反復計算 によって算出する。本解析の主な前提条件は以下のとおりとした。 (1) 加熱面の熱伝達

外部加熱によるコンクリート板への熱流入は, 放射熱伝達および 対流熱伝達によって生じるものとし, 試験体設置面を除いた炉の内 壁表面温度および炉内気体温度が図 3 に示した加熱温度に等しいと 仮定した。放射熱伝達は, 試験体設置面以外の各表面における平均 放射率を各構成材料の支配面積で重み付けして算定し, 炉内各面と 試験体面との合成放射率と形態係数を勘案して計算した注 1 。加熱面 側の対流熱伝達については, 火災室温度の算定に用いられている温 度依存性を考慮した対流熱伝達率9)を適用した。

\section{(2) 裹面側の熱伝達}

コンクリート板の裏面からの熱流出も放射熱伝達と対流熱伝達に よって生じるものとした。コンクリート面と周囲の合成放射率を
0.9, 形態係数を 1 として, 放射熱伝達を計算した。対流熱伝達は, 垂直平板における自然対流熱伝達 9) とした。コンクリート板裏面温 度と空気温度 $\left(20^{\circ} \mathrm{C}\right.$ 一定) の平均温度から空気の物性等を計算して, 対流熱伝達率を算定した。

(3) コンクリートの熱物性

コンクリートの熱物性として, EUROCODE 410)の普通コンクリ 一トに関する温度依存性を考慮した物性值を参照した。 EUROCODE 4 の熱伝導率を 0.8 倍, 比熱を 1.2 倍すると実験結果 と解析結果が良好に一致することが報告されており ${ }^{11)}$, 本解析でも これらの倍率を乗じた物性值を適用した。さらに, コンクリートの 温度は，その上昇過程において，含有水の潜熱によって $100^{\circ} \mathrm{C}$ 近傍 で停滞する。本解析では, $100^{\circ} \mathrm{C}$ で温度上昇の停滞が生じると仮定 し，蒸発に使われる熱量は $2256 \mathrm{~J} / \mathrm{g}$ とした。また，コンクリート内 部の水分は温度と圧力の変化によって移動するが, 本解析ではコン クリート内部の水分移動は考慮せず，解析要素内の含有水が $0 \%$ に なった時点から再度温度上昇するものとした。本解析では, コンク リートの含水率を $3 \mathrm{wt} \%$ とした。

\section{(2) 解析モデルと解析ケース}

(1)解析モデル

解析モデルおよび PL-3 と同条件で衝突実験を実施した試験体の 厚さ方向の切断面写真3)を図 6 に示寸。写真は裏面剥離しているが, 前述のように，裏面剥離していない断面を解析対象とした。

正方形板の試験体にクレーター状の表面破壊や円錐状の内部ひび 割れが形成されている状態を解析するのであれば，本来，3 次元モ デルが望ましいと考えらえる。しかし，表面破壊形状やコンクリー 卜板内部の斜めひび割れの状態については，それらを予測する技術 が確立されていないことから，数少ない試験体の断面観察によって
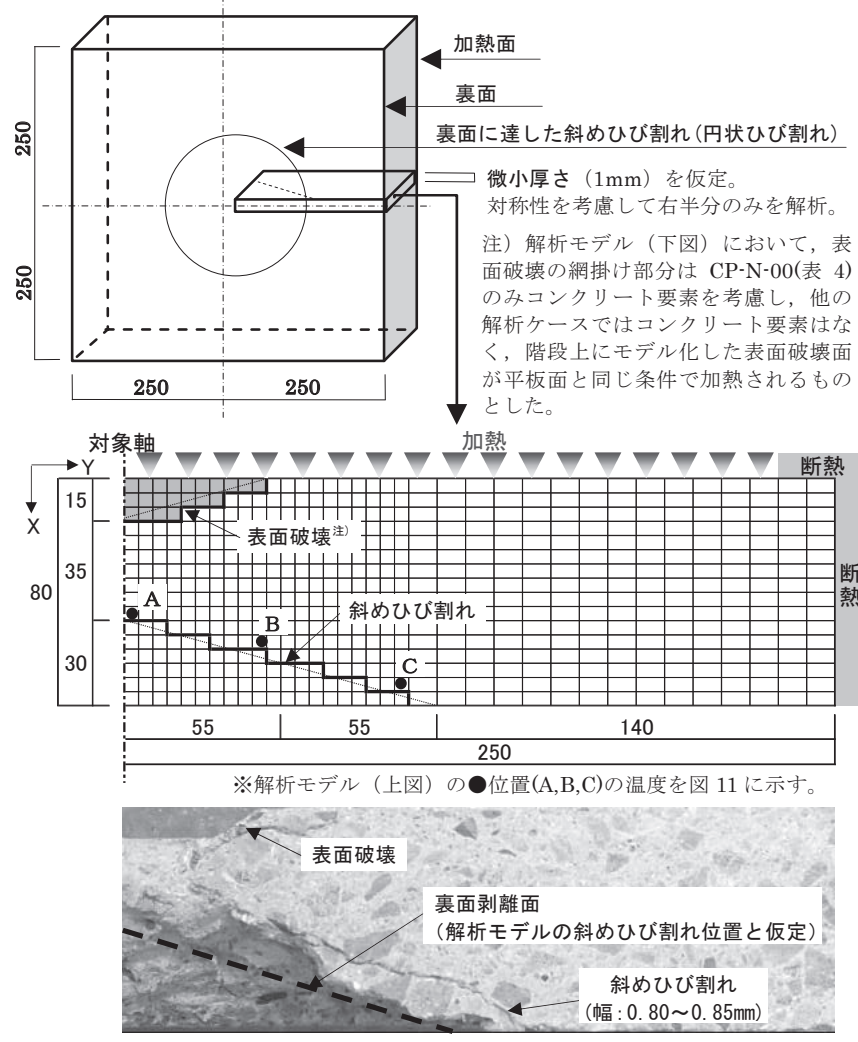

図 6 解析モデル（上） と PL-3 同等試験体 3)の切断面 
おり, 3 次元解析を実施するほどの詳細な入力データを得られない のが現状である。そのため本検討では, まずは簡易な解析で表面破 壊や斜めひび割れの影響を把握すべく, 図 6 に示すような単純な 2 次元モデルについて解析を行うことにした。

解析モデルは, コンクリート板中央高さの微小厚さ部分について 左右の対称性を考慮して $1 / 2$ 幅を切り出した 2 次元の断面とした。 対称軸から $10 \mathrm{~cm}$ までは $5 \mathrm{~mm} \times 5 \mathrm{~mm}$ メッシュ, 残りは $5 \mathrm{~mm} \times$ 10mm メッシュとした。表面破壊は PL-2, PL-3 および PP10-2 を 参照し, これらの高速衝突実験結果を概ね反映するように, 表面破 壊は深さ $15 \mathrm{~mm}$, 半径 $50 \mathrm{~mm}$ とした。また, 斜めひび割れについて は, 図 6 の試験体切断写真から, 裏面剥離面を含めると 2 箇所以上 で生じていたと推察されるが, 本解析では PL-3 の深さ $30 \mathrm{~mm}$, 半 径 $110 \mathrm{~mm}$ の裏面剥離面を斜めひび割れ位置とした。具体には, 解 析要素が四角形であることから, 表面破壊と斜めひび割れを階段状 にモデル化した。そのため, 斜めひび割れに関しては, ひび割れ先 端の裏面到達部の要素に対するひび割れの影響は小さいと考え, 若 干の誤差を許容して半径を $100 \mathrm{~mm}$ とした。

(2)斜めひび割れの熱抵抗

互いに接触する固体内を熱が伝わる場合，一般に温度分布は接触 面で不連続な温度差を生じる。これは接触面が熱抵抗となるからで あり, コンクリートにひび割れが生じた場合も, ひび割れ面で温度 分布が不連続になると言える。固体面間の熱抵抗は, 固体の熱伝導 率の他に, 接触面積（個体の降伏圧力や接触圧力によって変化）お よび接触面の空隙に介在する気体の熱伝導率（気体の圧力や空隙の 寸法によって変化）などに依存する ${ }^{12)}$ 。コンクリートにひび割れが 生じた場合の熱抵抗の導出にも接触面積や気体の熱伝導率が必要と いえるが，これらを算定するための情報は本研究の実験では得られ ていない。そこで, 本解析では, ひび割れ部の熱コンダクタンスを 低減して熱抵抗を模擬することとした。すなわち, 熱伝導を計算す る要素間の境界にひび割れがない場合の熱コンダクタンスはコンク リートの熱伝導率と熱エネルギーの移動が生じる要素間の面積の積 を要素の中心間距離で除した值となるが，ひび割れがある場合（要 素間の境界にひび割れがあると仮定 (図 6 参照)）には，要素間の 面積（接触面積）を小さくすることによって, 疑似的に熱抵抗を考 慮することにした。

(1)で述べたように本解析では，斜めひび割れを要素間の境界に階 段状にモデル化しているため, $\mathrm{X}$ 方向と $\mathrm{Y}$ 方向に対する斜めひび割 れの影響を考える必要がある。図 6 に示すように, $\mathrm{Y}$ 軸に対する斜 めひび割れの角度は，X 軸に対する角度よりも小さい。熱伝導方向 とひび割れの成す角度が小さいほど(平行に近いほど)熱伝導に対す るひび割れの影響は小さく, 角度が大きいほど（垂直に近いほど） 影響は大きいと言える。そこで, 参照した斜めひび割れの勾配 30/110 を考慮して, X 方向の熱コンダクタンスの低減率に 30/110 を乗じた值を Y 方向の熱コンダクタンスの低減率とした。

(3)解析ケース

解析ケースを表 4 に示す。解析ケースは, 無損傷のコンクリート 板, 表面破壊のみのコンクリート板, 表面破壊と斜めひび割れの生 じたコンクリート板とした。斜めひび割れについては, 熱抵抗とひ び割れ長さについて検討した。ひび割れ長さは，局部破壊モードが 表面破壊の場合でも, 短繊維補強の有無や衝突速度等によって異な
表 4 解析ケース

\begin{tabular}{|c|c|c|c|c|}
\hline \multirow[t]{2}{*}{ 解析名 } & \multirow{2}{*}{$\begin{array}{c}\text { 表面破壊 } \\
\text { の有無 }\end{array}$} & \multirow{2}{*}{$\begin{array}{c}\text { 斜めひび割れ } \\
\text { の有無 }\end{array}$} & \multicolumn{2}{|c|}{$\begin{array}{c}\text { 斜めひび割れ部 } \\
\text { 熱コンダクタンス低減率 }(\%)\end{array}$} \\
\hline & & & X方向 & Y方向 $\%$ \\
\hline $\mathrm{CP}-\mathrm{N}-00$ & なし & なし & 0.00 & 0.00 \\
\hline $\mathrm{CP}-\mathrm{S}-00$ & あり & なし & 0.00 & 0.00 \\
\hline $\mathrm{CP}-\mathrm{S}-50$ & あり & あり & 50.00 & 13.63 \\
\hline $\mathrm{CP}-\mathrm{S}-95$ & あり & あり & 95.00 & 24.55 \\
\hline CP-S-95H & あり & あり (半長) & 95.00 & 25.91 \\
\hline
\end{tabular}

※Y方向の低減率はX方向の低減率に30/110を乗じた值とした。

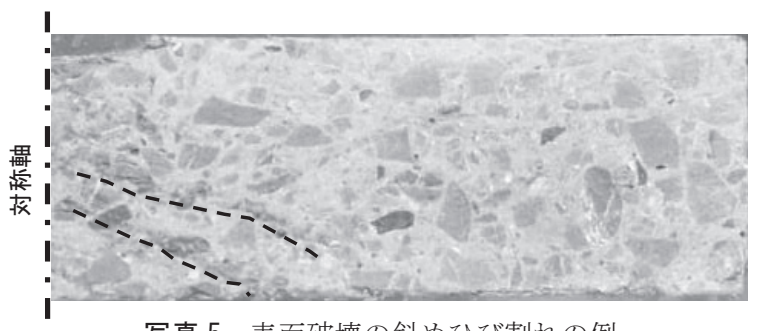

写真 5 表面破壊の斜めひび割れの例

(上側が衝突面，ひび割れの下側を点線でトレース）

る。そこで, 写真 5 に示すように斜めひび割れの先端が裏面に達し ない場合を想定し, ひび割れ先端が裏面に到達する場合の半分の長 さ（図 6 において,ひび割れの先端が対称軸から $55 \mathrm{~mm}$ の位置で止 まった状態）についても解析を行った。表 4 の解析名は，表面破壞 の有無 $(\mathrm{N}, \mathrm{S})$, 斜めひび割れ部の熱コンダクタンスの $\mathrm{X}$ 方向の低 減率で表記し，ひび割れ長さを半分にした場合には’H'を付した。

解析では，まず， CP-N-00 と CP-S-00 を比較して, 裏面温度に 対する表面破壊の影響範囲を確認した。そして，衝突実験による損 傷が小さく, 熱画像（写真 3）において斜めひび割れの影響が見ら れない PP10-2 に関して, 表面破壊の影響がないと推定される位置 の裏面温度について計算結果と実験結果の比較を行い, 斜めひび割 れがない場合の計算の妥当性を検証した。次に，衝突によって生じ た斜めひび割れが温度性状に与える影響に関する検討を行った。

\section{（3）解析結果および考察}

(1) 裏面温度に対する表面破壊の影響範囲

図 7 に表面破壊の有無をパラメータにした CP-N-00 と CP-S-00 に関する裏面温度と対称軸からの距離の関係を示す。両者の裏面温 度は, 対称軸から離れるにしたがって差が小さくなっている。そし て, 対称軸から $150 \mathrm{~mm}$ 以上離れた位置では, 表面破壊の影響は裏 面温度に及ばないと判断される。

(2) 裏面温度に関する実験結果と計算結果の比較

図 8 に裏面温度の経時変化に関寸る P10-2 の実験結果と CP-S-00 の計算結果を示す。上記(1)から表面破壊の影響が及ばない，対称軸 から $150 \mathrm{~mm}$ の裏面温度を図に示した。実験值は, 縦対称軸から $150 \mathrm{~mm}$ の位置における中央高さ $\pm 10 \mathrm{~cm}$ の範囲の温度を熱画像か ら画像解析ソフトを用いて 5 分間隔で読み取った。実験值と計算值 を比較すると, 加熱初期の温度と $100^{\circ} \mathrm{C}$ 近傍の蒸発潜熱による温度 停滞に違いはあるが, 裏面温度の経時変化の傾向は概ね一致してい る。加熱開始後 55 分以降は実験值と計算值が良く一致した。

なお，常温から $100^{\circ} \mathrm{C}$ 程度までは，コンクリート中の含水分が多 いほど熱伝導率が高くなる傾向があることや，当該水分の移動が熱 伝導率を大きく寸る可能性のあることが既往の研究で示されている 13,14)。計算では，コンクリート中の水分移動やその結果によって生 じる含水率の変化を考慮していないため, 加熱初期の温度が実験よ りも低くなったのではないかと推察される。 
以上から，コンクリート中の水分移動を考慮していないことが本 報で用いた解析方法の改善点として挙げられるが，この点を除けば 実験結果を概初再現できており, 本計算方法は以下の温度性状の検 討に適用できるものと判断される。

(3) 裏面温度に対寸る斜めひび割れの影響

図 9 に裏面温度と対称軸からの距離の関係に関する, P10-3 の実 験結果および CP-S-95 と CP-S-95H の計算結果を示す。実験值は, 試験体の縦対称軸から右半分の試験体中央高さ位置(解析モデル(図 6）の断面を抜き出した位置）における裏面温度を熱画像から画像 解析ソフトを用いて読み取った。なお, 本報では, 熱コンダクタン 不低減率 0，50，95\%の解析を示したが，これら以外に，10，20， 90\%の低減率についても解析を行った。その結果, 対称軸から $0 \mathrm{~mm}$ の位置における裏面温度に関して, 低減率 95\%の計算結果が P10-3 に近い結果を示したことから, CP-S-95 と CP-S-95H を10-3 の比 較対象とした。

CP-S-95 と CP-S-95H の裏面温度を比較すると, 対称軸から 30 〜 100mm 程度の範囲で CP-S-95の方が CP-S-95Hよりも低くなり, 設定した斜めひび割れの長さの影響が認められるが，対称軸から $110 \mathrm{~mm}$ 以上離れると両者の裏面温度に差はない。30 分における実 験值と計算值の違いは，(2)で述べたように，水分移動の影響がある と推察される。60，90，120 分における対称軸から斜めひび割れ裏 面到達位置までの裏面温度は, 実験值が CP-S-95 と CP-S-95H の計 算值の間にあり, ひび割れ長さを CP-S-95H よりも長くすると実験 結果に近い計算結果が得られるものと考えられる。なお，コンクリ 一ト板端部の裏面温度の計算值が実験值よりも高くなったのは, 端 部を完全断熱として計算したためだと考えられる。

図 10 に, CP-S-00, CP-S-50, CP-S-95 および CP-S-95H に関し て，60，120 分におけるコンクリート板の断面温度分布を示すとと もに, 120 分における裏面温度分布および斜めひび割れ下方領域(解 析モデル（図 6）において階段状の斜めひび割れ, 裏面および対称 軸で囲まれた領域）の平均温度の経時変化を示す。解析結果を比較 すると, 斜めひび割れの裏面到達位置よりも外側（対称軸から $110 \mathrm{~mm}$ 以上離れた範囲）では裏面温度に違いは見られず, それよ りも内側では, 斜めひび割れが裏面に到達し, かつ熱コンダクタン スの低減率の大きい方が裏面温度は低くなった。

裏面温度に対する斜めひび割れの影響は, 写真 4 と図 5 に示した P05-3 で比較的明確に認められる。P05-3（図 5）と CP-S-95（図 10 のグラフ）の 120 分時の裏面温度を比較すると, 斜めひび割れ の内側と外側の温度が P05-3 では $240^{\circ} \mathrm{C}$ と $293^{\circ} \mathrm{C}$ (温度差 $53^{\circ} \mathrm{C}$ ), CP-S-95 では $226^{\circ} \mathrm{C}$ と $286^{\circ} \mathrm{C}$ (温度差 $60^{\circ} \mathrm{C}$ ) となっており, 実験結 果と計算結果が概ね同等な傾向を示している。

以上の計算結果から，実験結果と同様に，斜めひび割れはコンク リート板の遮熱性能の弱点にはならないと言える。

\section{(4) 内部温度に対する斜めひび割れの影響}

図 11 に，CP-S-00，CP-S-50，CP-S-95 および CP-S-95H に関し て, 斜めひび割れの加熱側に沿った温度（解析モデル（図 6）の A, $\mathrm{B}, \mathrm{C}$ 点）の経時変化を示す。これらの温度は CP-S-00<CP-S-50 $<$ CP-S-95H $<$ CP-S-95 の順に高く, 120 分における CP-S-95 の温 度は CP-S-00 よりも A 点で約 $160^{\circ} \mathrm{C}, \mathrm{B}$ 点で $120^{\circ} \mathrm{C}, \mathrm{C}$ 点で約 $60^{\circ} \mathrm{C}$ 高い。これに対して, 斜めひび割れ下方領域では, 図 10 の斜めひ

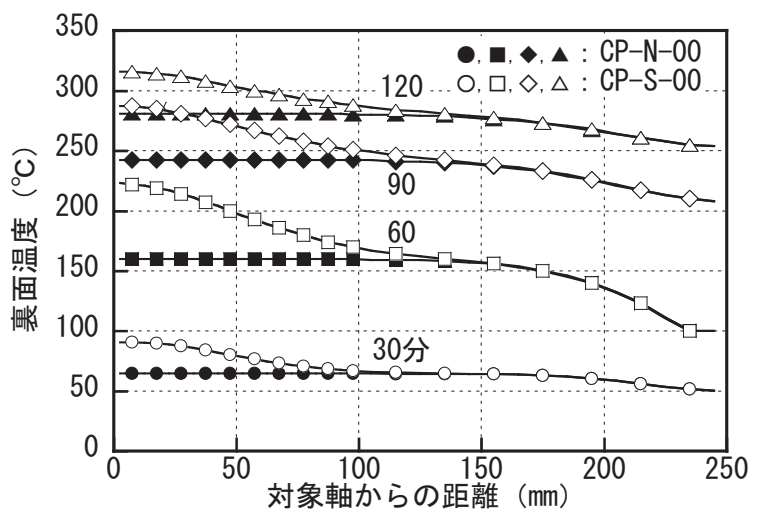

図 7 表面破壊の有無が裏面温度に及ぼす影響 (CP-N-00 と CP-S-00 の比較)

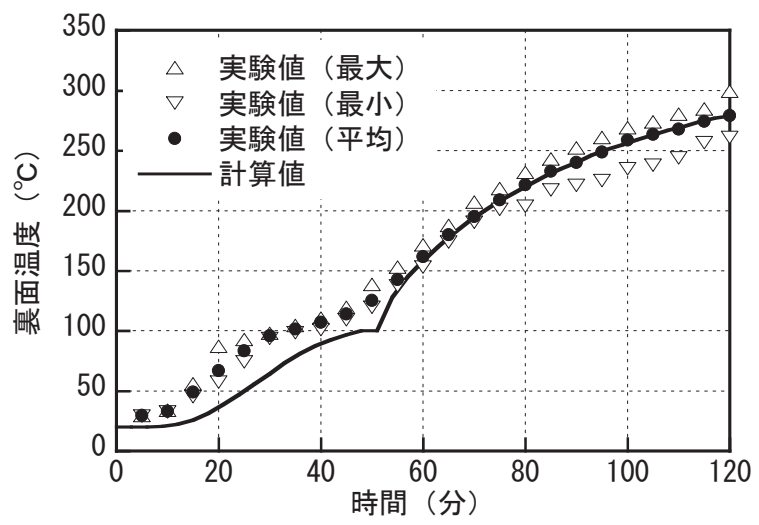

図 8 実験結果（P10-2） と計算結果（CP-S-00）の比較 (対称軸から $150 \mathrm{~mm}$ の裏面温度)

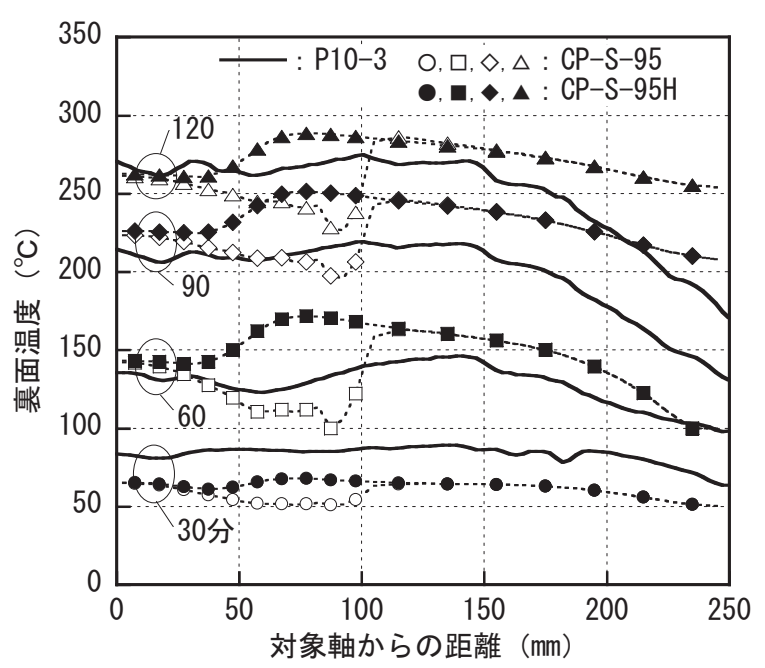

図 9 実験結果 (P10-3) と計算結果 (CP-S-95,95H) の比較 (裏面温度と対称軸からの距離の関係)

び割れ下方領域の平均温度のグラフに示されるように, CP-S-00> CP-S-50>CP-S-95H > CP-S-95 の順に温度が低い。このような計算 結果になったのは，ひび割れによる熱抵抗を熱コンダクタンスの低 減によって疑似的に考慮したことに因っている。すなわち，ひび割 れ面は熱を伝えにくい断熱層的な役割を果たしているため，裏面側 への熱伝導が抑制され，ひび割れ面の加熱側の温度が高くなり，ひ び割れ面の裏面側の温度が低くなったと言える。

この計算結果に関して, 火災時の構造耐力の観点から以下に考察 する。コンクリートの耐力壁を想定すると，高速衝突によって生じ 


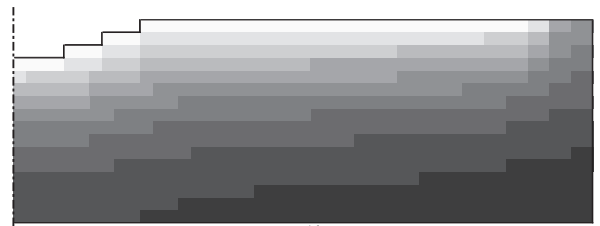

60 分

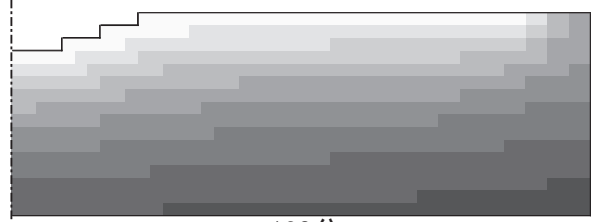

120分

【CP-S-00】

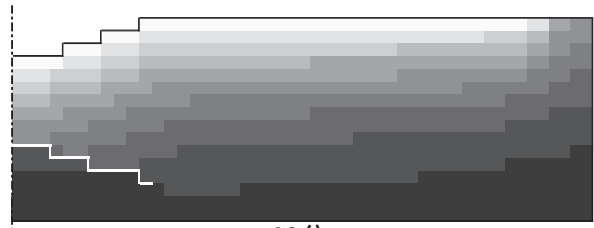

60 分

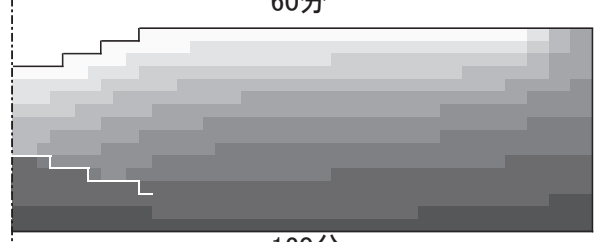

120分

[CP-S-95H】

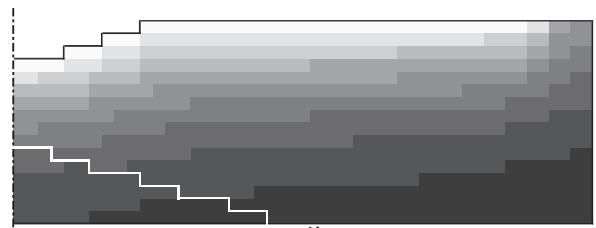

60分

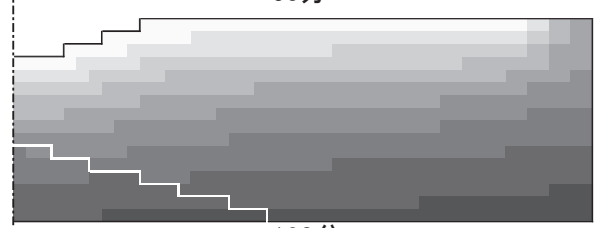

120分

【CP-S-50】

$\left({ }^{\circ} \mathrm{C}\right)$

$1000-1100$ 900-1000 $800-900$ $700-800$ $600-700$ $500-600$ $400-500$ $300-400$ $200-300$ $100-100$ 20-100

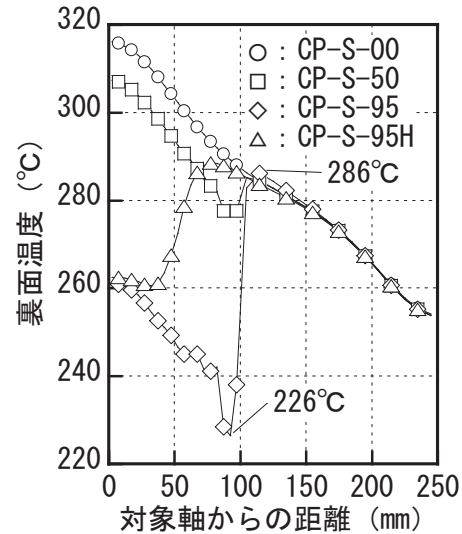

【120 分の裏面温度分布】

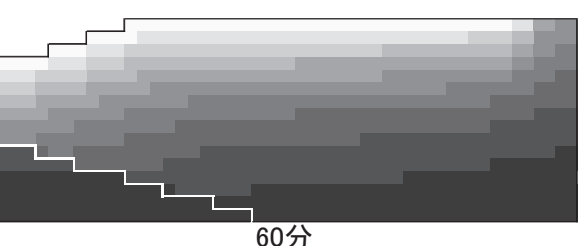

60 分

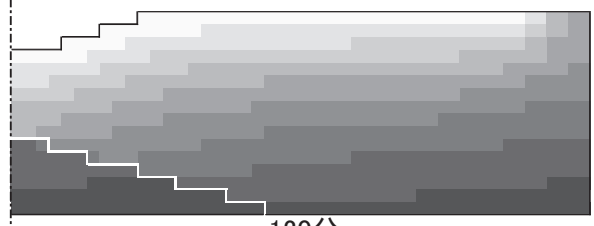

120分

【CP-S-95】

図 10 コンクリート板の断面温度分布, 裏面温度分布および斜めひび割れ下方領域の平均温度の経時変化

た表面破壞や斜めひび割れは耐力を低下させる要因となる。当該壁 が火災加熱を受けると部材温度の上昇によってコンクリートや鋼材 の力学的特性が低下寸るため ${ }^{15)}$, 火災時にはさらに耐力が低下寸る。 斜めひび割れがある場合には，斜めひび割れの加熱側（荷重を支持 する残存断面側）に沿って内部温度が高くなる傾向が本解析によっ て確認された。斜めひび割れは内部温度上昇に影響することから， 火災時構造耐力を評価する上では, 斜めひび割れによる力学的な影 響だけでなく，熱的な影響も考慮する必要があると考えられる。

\section{6. 結論}

剛飛翔体の衝突によって損傷したコンクリート板が衝突面側から 火災加熱を受けた場合の温度性状を把握することを目的として，コ ンクリート板に対する高速衝突実験と加熱実験を実施するとともに, 高速衝突を受けて局部破壊したコンクリート板が火災加熱を受けた 場合を想定した伝熱解析を行った。本検討で得られた知見は以下の とおりである。

\section{(1) 高速衝突実験}

衝突速度 $315 \mathrm{~m} / \mathrm{s}$ の実験において, 短䋊維補強していないコンク リート板では裏面剥離を生じた。短繊維補強したコンクリート板で は, 内部に斜めひび割れが形成されていたが, 裏面剥離を生じなか った。本実験によって, 既報 ${ }^{3)}$ で報告した結果と同様に, 短繊維補 強が局部破壊の抑制に効果のあることが確認された。

\section{（2）加熱実験結果}

・加熱期間・冷却期間を通じて，コンクリート板の加熱面と裏面か らコンクリート片が剥落するなどの外見上の損傷の拡大は認めら れず，板内部に生じた斜めひび割れがコンクリート片の剥落に影

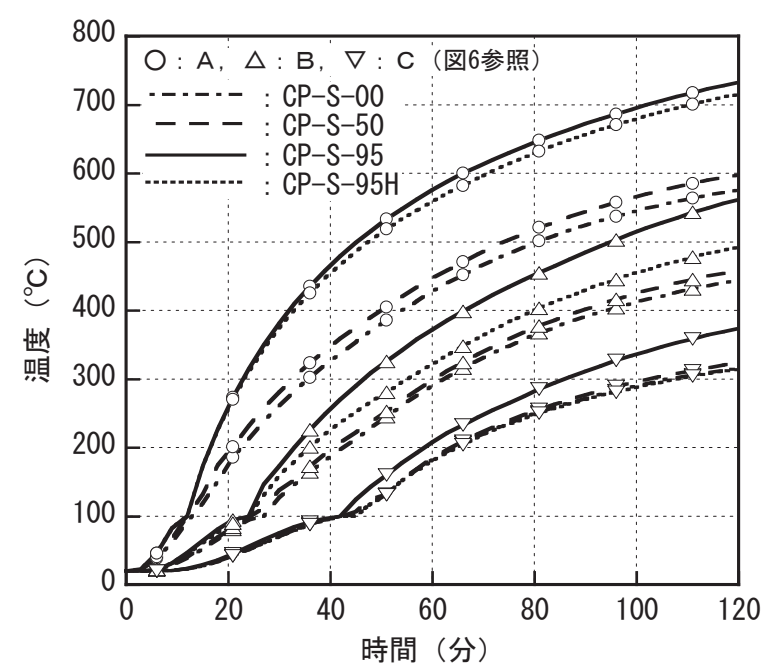

図 11 斜めひび割れの加熱側に沿った温度の経時変化 （解析モデル（図 6）の A， B， C 点の温度）

響しないことが確認された。

・衝突によって生じた放射状ひび割れと円状ひび割れ（斜めひび割 れ）を通じて，加熱初期に，コンクリートの裏面温度よりも 20 $\sim 30^{\circ} \mathrm{C}$ 程度高い含有水が裏面に湧出した。しかし, 短時間でその 温度差はなくなり, 高速衝突によって生じたひび割れは遮熱性能 上の弱点にならないことが確認された。

・斜めひび割れが裏面まで達しない場合，表面破壊で生じた断面欠 損によって表面破壊位置の真裏の裏面温度が若干高くなる傾向が 見られた。一方, 斜めひび割れが裏面付近まで達した場合, 斜め ひび割れによる熱抵抗の増加により，裏面温度に対する表面破壊 
の影響が低減されることが確認された。斜めひび割れを生じても， 裏面剥離を防止することが遮熱性能の確保に重要であると言える。

\section{（3） 温度性状解析}

・裏面温度に関して実験結果と計算結果を比較した結果, 常温から $100^{\circ} \mathrm{C}$ 程度までの温度上昇は実験值よりも計算值の方が低くなっ たが, $100^{\circ} \mathrm{C}$ 以降の計算值は実験值と一致した。これにより，本検 討で用いた解析方法は概初妥当であることが確認された。ただし, $100^{\circ} \mathrm{C}$ 程度までの差異については, コンクリート中の細孔やひび割 れを通じての水分移動を考慮していないことが原因と考えられ， これらを伝熱解析で考慮することが今後の課題である。

・斜めひび割れが裏面に到達する位置よりも外側では裏面温度に対 する斜めひび割れの影響は見られず，また，斜めひび割れが裏面 に到達する位置よりも内側では斜めひび割れがない場合に比べて 裏面温度が低くなった。実験結果と同様に, 解析によっても斜め ひび割れは遮熱性能上の弱点にならないことが確認された。

・実験では確認できなかった内部温度に対する斜めひび割れの影響 を検討した結果, 斜めひび割れの加熱側に沿った温度が斜めひび 割れのない場合に比べて $60 \sim 160^{\circ} \mathrm{C}$ 程度高くなることが確認され た。高速衝突を受けたコンクリート壁の火災時耐力の評価では, 斜めひび割れによる力学的な影響と熱的な影響の双方を考慮する 必要があると考えられ，今後の検討課題である。

・実験結果に近似した計算結果を得るために, 斜めひび割れによる 熱抵抗の増加を熱コンダクタンスの低減によって考慮した。その 結果, 熱コンダクタンスは, 加熱面に垂直な方向で 95\%低減し, かつ加熱面に平行な方向で $95 \%$ の 30/110（ひび割れ角度を考慮） に低減しなければならないことがわかった。斜めひび割れの本 数・幅・長さの予測, ならびにひび割れ幅と熱コンダクタンスの 低減率の関係を定量化することが今後の課題として挙げられる。

\section{参考文献}

1) 土木学会構造工学委員会衝撃問題研究小委員会 : 構造物の衝撃挙動と設 計法, 構造工学シリーズ $6,1994.1$

2) 日本建築学会構造委員会応用力学運営委員会: 衝突・爆発などの衝撃的 な外力による構造被害の低減化について考える, 2009 年度日本建築学会 大会 (東北) 構造部門 (応用力学) パネルディスカッション資料, 2009.8

3）森田武, 別府万寿博, 鈴木誠: 高速衝突を受けるポリプロピレン短䋐維 補強コンクリートの耐衝撃性能, 日本建築学会構造系論文集, 第 684 号, pp.319-327, 2013.2

4) 別府万寿博, 三輪幸治, 大野友則, 塩見昌紀 : 鋼製剛飛翔体の高速衝突 を受けるコンクリート板の局部破壊に関する実験的研究, 土木学会論文 集, Vol.63, No.1, pp.178〜191, 2007.3

5) EUROCODE 1: Basics of design and actions on structures Part 2-2: Actions on structures exposed to fire, European Committee for Standardization, 1994

6）若松孝旺：火災時における建物部材の内部温度算定に関寸る研究（第一 報）一算定式の誘導，算定条件および算定要素一, 日本建築学会論文報 告集，第 109 号，pp.73〜 79，1965.3

7）若松孝旺：火災時における建物部材の内部温度算定に関する研究（第二 報) 一算定式の解法一, 日本建築学会論文報告集, 第 111 号, pp. 31 36, 1965.5

8) Morita, T., Wakamatsu, T., Uesugi, H., and Saito, H. : Analyses of Composite Beams and Frames at Elevated Temperature, Fire Safety Science - Proceedings of the Third International Symposium on Fire Safety Science, pp.761 770, 1991.

9）田中㫴義: 建築火災安全工学入門，日本建築センター, 2002
10) EUROCODE 4: Design of composite steel and concrete structures Part 1-2: General rules - Structural fire design, European Committee for Standardization, 1994

11）齋藤秀人，森田武，上杉英樹：中心圧縮を受ける充填鋼管コンクリート 柱の内部温度と耐火時間に関する研究, 日本建築学会環境系論文集, 第 582 号, pp. 9-16, 2004.8

12）甲藤好郎：伝熱概論, 養賢堂, 1972

13）原田有：建築耐火構法, 工業調査会, 1973

14）李在永, 權寧璡, 原田和典 : 各種強度コンクリートの高温時の熱伝導率 の推算方法に関する研究, 日本建築学会大会学術講演梗概集, A-2, pp.61 $\sim 62,2010.7$

15）日本建築学会 : 構造材料耐火性ガイドブック，2009.3

\section{注}

注1）試験体加熱面への放射熱伝達の算定

小型壁炉と試験体の設置に関する模式図を付図1に示す。

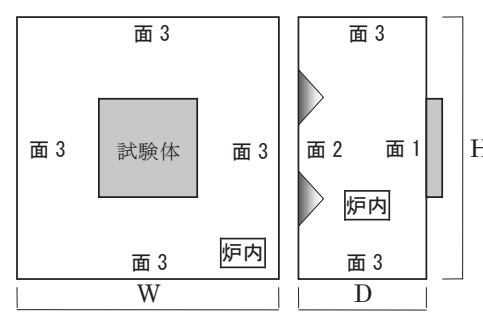

正面図
縦断面図
【炉内面の構成】

面 1 : 試験体面（コンクリート） 面 2 ：バーナ一設置面（バーナー火炎，

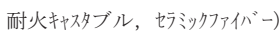
面 3 : 試験体に対して垂直な面(上

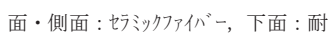
火キャスタブル

【放射率】 コンクリート : 0.9, ベーナー火炎 : 0.2 , 而

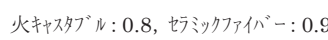

付図 1 小型壁炉と試験体の設置に関する模式図
加熱時に炬から試験体に正味伝達される放射エネルギーは式1)で計算する。

$$
\begin{aligned}
Q_{2.3 \rightarrow 1}=\sigma & \cdot A_{1} \cdot\left(\varepsilon_{1} \varepsilon_{2} F_{12}+\varepsilon_{1} \varepsilon_{3} F_{13}\right) \cdot\left(T_{f}^{4}-T_{1}^{4}\right) \\
こ こ に, & Q_{2,3 \rightarrow 1}: \text { 面 } 2,3 \text { から面 } 1 \text { (試験体) に正味伝達される放射エネル } \\
& \text { ギー, } \sigma: \text { ステファンボルツマン定数, } A: \text { 面積, } \mathcal{E} \text { : 放射率, } \\
& F \text { : 形態係数, } T: \text { 炉内または試験体面の絶対温度, 下付き文字 : } \\
& \text { 数字は付図 } 1 \text { の面位置を, fは炉内を表す。 }
\end{aligned}
$$

各面の放射率（平均放射率）は式2)で計算する。

$\varepsilon_{i}=\sum_{j}\left(A_{j} \cdot \varepsilon_{j}\right) / \sum_{j} A_{j}$

ここに, $A$ : 面積, 下付き文字 : 引は面位置を, 引は $i$ 面の構成材料を表す。

面1 (試験体) の中心の面積要素（微小面 $d 1 ）$ から面2を見たときの形態係 数は式3)で計算し，面1から面2を見る形態係数は式4)で計算する。また， 面1から面3を見る形態係数は式5)で計算できる。

$$
\begin{aligned}
& \left.\left.F_{d 1 \rightarrow 2}=4 \cdot\left[\frac{1}{2 \pi}\left(\frac{X}{\sqrt{1+X^{2}}}\right) \tan ^{-1} \frac{Y}{\sqrt{1+X^{2}}}+\left(\frac{Y}{\sqrt{1+Y^{2}}}\right) \tan ^{-1} \frac{X}{\sqrt{1+Y^{2}}}\right]\right\} 3\right) \\
& X=(W / 2) / D, \quad Y=(H / 2) / D \\
& \text { ここに, W : 炉の幅 }(\text { 付図 } 1), \mathrm{H}: \text { 炉の高さ, D : 炉の奥行。 } \\
& F_{1 \rightarrow 2}=F_{d 1 \rightarrow 2} \\
& F_{1 \rightarrow 3}=1-F_{1 \rightarrow 2}
\end{aligned}
$$

面 $2 お よ ひ ゙$ 面3に関して各面の構成材料の放射率と面積を式 2 )に代入するこ とで各面における平均放射率が算定され, 式3)に炉の具体的な内法寸法を 代入することで面 1 から面 2 と面 3 を見る形態係数が算定される。これらの 算定值を用いて式1)の $\left(\mathcal{E}_{1} \mathcal{E}_{2} F_{12}+\mathcal{E}_{1} \mathcal{E}_{3} F_{13}\right)$ を計算すると 0.74 となる。これ により, 式1)において炉内温度と試験体表面温度以外は既知の值となり, 炉内温度に標準加熱温度一時間関係を与えて差分法を適用した逐次計算を 行うことにより, 試験体表面温度および内部温度が求められる。 